DOI: $10.5277 /$ epe 160407

\author{
EMINE ELMASLAR ÖZBAŞ ${ }^{1}, \mathrm{H}$. KURTULUŞ ÖZCAN ${ }^{1}$, ATAKAN ONGEN ${ }^{1}$
}

\title{
EFFICIENCY OF MSW COMPOST FOR REDUCING UPTAKE OF HEAVY METALS BY PLANT
}

\begin{abstract}
Municipal solid waste (MSW) compost supplied from the Istanbul Solid Waste Recycling and Composting Facility was used to amend soil samples collected within the boundaries of Istanbul. Cat grass (Dactylis glomerata cat grass) seeds were sown in the prepared samples. Plant development was observed for 90 days. $\mathrm{pH}, \mathrm{Cd}, \mathrm{Cu}$ and $\mathrm{Ni}$ concentrations in plant samples were measured at the end of every month. Concentrations of forms of $\mathrm{Cd}, \mathrm{Cu}$ and $\mathrm{Ni}$ forms in soil were determined at the beginning and at the end of 90 day period (with sequential extraction). The effect of MSW compost on the transfer of $\mathrm{Cd}, \mathrm{Cu}$ and $\mathrm{Ni}$ from the soil to the plants and the change in the forms of heavy metals in soil was determined. Results of sequential extraction showed that, adding compost into the soil changed the forms of these metals in soil. Plant uptake of $\mathrm{Cd}$ decreased, however, those of $\mathrm{Ni}$ and $\mathrm{Cu}$ increased. $\mathrm{Cu}$ concentration in plants that grew in soil with 3 wt. \% of compost added reached $136.4 \mu \mathrm{g} / \mathrm{kg}$.
\end{abstract}

\section{INTRODUCTION}

Heavy metal pollution has raised serious environmental concerns worldwide. Bioaccumulation of heavy metals, which do not undergo microbial or chemical degradation, poses long term risk to the ecosystem $[1,2]$. Organic soil amendments such as composts are now established amongst in-situ methods instead of expensive and disruptive hardengineered ex-situ methods [3].

Composting is an environmentally effective solid waste disposal method as it reduces domestic solid waste $50 \%$ by volume and weight and as the obtained compost is used as a soil improvement material in agricultural areas [4]. The use of compost obtained from municipal solid wastes as soil enrichment substance for agricultural purposes has advantages in terms of ecology and recycling of organic substances. However, certain heavy metals, especially $\mathrm{Pb}, \mathrm{Cd}, \mathrm{Cu}$ and $\mathrm{Zn}$, are known to accumulate in soil structure during the use of compost for agricultural purposes. Contamination of soil with

${ }^{1}$ Istanbul University, Engineering Faculty, Environmental Engineering Department, 34320, Avcilar, Istanbul, Turkey, corresponding author: E. E. Özbaş, e-mail: elmaslar@ istanbul.edu.tr 
these heavy metal compounds and uptake of toxic substances by plants causes various problems in terms of ecology.

There is a large body of literature on the transfer of heavy metals in the composition of compost that is obtained from domestic solid wastes to plants [5-7]. Wu et al. [8] applied compost to rice plant in greenhouse environment and analyzed the uptake of $\mathrm{Cd}$ and $\mathrm{Pb}$ by the plants. The literature also contains studies involving EDTA assisted phytoextraction of heavy metals from municipal solid waste compost [9] and heavy metal removal from compost using zeolite [10]. Carbonell et al. [11] analyzed the transfer of heavy metals in compost by maize (Zea mays L.) plant and reported that $\mathrm{Cu}, \mathrm{Pb}, \mathrm{Zn}$ levels increased after adding compost.

The aim of this study was to analyze the effect of the use of compost on the transfer of heavy metals in soil to the plant and metal mobility. MSW compost supplied from Istanbul Solid Waste Recycling and Composting Facility was used in the study. Soil samples were collected within the boundaries of Istanbul province. Tests conducted in pots aimed to determine the effect of MSW on heavy metal amounts that was transferred to cat grass plant. The study also determined the effect of MSW compost on the change of heavy metal forms in the soil.

\section{EXPERIMENTAL PROCEDURES}

Municipal solid waste (MSW) compost samples were obtained from the Istanbul Solid Waste Recycling and Composting Facility, Turkey. The soil used in the study was collected from a roadside area around Istanbul coastal road in Dragos $\left(40^{\circ} 55^{\prime} \mathrm{N}, 29^{\circ} 8^{\prime} \mathrm{E}\right)$.

Characterization of soil and compost samples. For determining the $\mathrm{pH}$ values of the compost samples, distilled water was added to the samples at a 5:2(v/w) ratio. The measurement of $\mathrm{pH}$ values were carried out using a $\mathrm{pH}$ meter (Jenway 3040 Ion Analyzer), after being mixed by a magnetic mixer for $10 \mathrm{~min}$. For determining soil $\mathrm{pH}$, a Jenway $3051 \mathrm{pH}$ meter and SIS electrode were used. $\mathrm{pH}$ determination was carried in a 1:2.5 soil:water suspension.

TS 8340 method was used to detect available $\mathrm{P}$ concentrations of compost samples analysed colorimetrically as molybdovanadophosphoric acid $[13,14]$. The percentages of $\mathrm{C}, \mathrm{H}, \mathrm{N}$ and $\mathrm{S}$ in the compost and soil samples were determined using elemental analyser in the Advanced Analysis Laboratory (IAL) of Istanbul University. Samples were dried at $50{ }^{\circ} \mathrm{C}$ for $24 \mathrm{~h}$ and ground to a fine powder in a quartz mortar before the elemental analysis. The equipment specifications were as follows: Thermo Finnigan Flash EA 1112 Series Elemental Analysis device, temperature $900{ }^{\circ} \mathrm{C}$; mobile gas $\mathrm{He}$, burning gas $\mathrm{O}_{2}$.

Soil and compost samples were air dried and then sieved to pass a $2 \mathrm{~mm}$ mesh for determination of total $\mathrm{Ni}, \mathrm{Cd}$ and $\mathrm{Cu}$ concentrations. Trace element total concentrations 
were determined by ICP-OES (Iris Intrepid II XDL, Thermo Scientific in CEBAS, Spain) after microwave assisted (Ethos1, Milestone) aqua regia digestion. Accuracy was routinely checked by reference digests of standard reference soils (SRM 2711, CMI7004). The analytical precision that measured as relative standard deviation was routinely between 3 and 5\%.

A sequential extraction was used to evaluate the distribution of $\mathrm{Ni}, \mathrm{Cd}$ and $\mathrm{Cu}$ elements in various chemical fractions of the soil [15].The method included the following steps:

1. $0.1 \mathrm{M} \mathrm{CaCl}_{2}(1: 10, \mathrm{w} / \mathrm{v})$ for $16 \mathrm{~h}$ : metals in soil solution and in exchangeable forms.

2. $0.5 \mathrm{M} \mathrm{NaOH}(1: 10, \mathrm{w} / \mathrm{v})$ for $16 \mathrm{~h}$ followed by aqua regia digestion: metals associated with organic matter $(\mathrm{OM})$.

3. $0.05 \mathrm{M} \mathrm{Na}_{2} \mathrm{H}_{2}$ EDTA $(1: 10$, w/v) for $1 \mathrm{~h}$ : metals which can be extracted by a strong chelator.

4. Digestion with aqua regia: residual metals.

$\mathrm{Ni}, \mathrm{Cd}$ and $\mathrm{Cu}$ concentrations of extracts obtained at each stage were measured with Hach-Lange DR 5000 photometer, LCK 337 kit (measurement range $0.1-6 \mathrm{mg} / \mathrm{dm}^{3}$ ) was used for $\mathrm{Ni}$; LCK308 kit (measurement range $0.02-0.3 \mathrm{mg} / \mathrm{dm}^{3}$ ) was used for Cd; LCK 529 kit (measurement range $0.01-1 \mathrm{mg} / \mathrm{dm}^{3}$ ) was used for $\mathrm{Cu}$.

Determining metal contents in plant samples. In this study, the following symbols were used for the soil samples: original soil - OS, C - control (soil sample without seeds), soil without compost (soil sample that planted seeds) $-\mathrm{C} 0$, and soil samples with added 1 and 3\% (v/v) of compost - C1 and C3, respectively. Samples C0, C1 and C3 were placed in $400 \mathrm{~cm}^{3}$ plastic pots. No seeds were planted in two of the pots in which soil without compost was placed (control samples). $1 \mathrm{~g}$ of Dactylis glomerata cat grass seed was planted in other pots. Three pots were used for each treatment. All pots were regularly watered with distilled water.

The plants that grew in pots were harvested $2 \mathrm{~cm}$ above the soil surface using stainless steel scissors at the end of each one month period. Plant samples were first washed with tap water and then two times with distilled water and dried in an incubator at $60{ }^{\circ} \mathrm{C}$. Plant samples were prepared for analysis by applying microwave dissolution procedure (by adding $10 \mathrm{~cm}^{3}$ of $\mathrm{HNO}_{3}$ into $1 \mathrm{~g}$ sample). Then ICP-MS (Thermo-Elemental ICPMS-X Series) device was used to determine $\mathrm{Ni}, \mathrm{Cd}$ and $\mathrm{Cu}$ concentrations in plant samples. All the analyses were done in duplicate and mean values were calculated.

\section{RESULTS AND DISCUSSION}

\subsection{SOILS}

Characterization of soil and compost samples is presented in Table 1. Initial $\mathrm{Ni}, \mathrm{Cd}$ and $\mathrm{Cu}$ concentrations in soil were found to be $44.64,181.64$ and $48.89 \mathrm{mg} / \mathrm{kg}$, respectively. $\mathrm{Ni}, \mathrm{Cd}$ and $\mathrm{Cu}$ concentrations in the compost were found to be $28.00,1.00$ and 
$127.00 \mathrm{mg} / \mathrm{kg}$, respectively. The concentration of $\mathrm{Cd}$ in this soil sample was very high $(181.64 \mathrm{mg} / \mathrm{kg}$ ). The average natural abundance of cadmium in the earth's crust has been reported from 0.1 to $0.5 \mathrm{mg} / \mathrm{kg}$. However, much higher and much lower values have also been cited depending on some factors. For example, phosphate fertilizers contain from 10 to $200 \mathrm{mg} / \mathrm{kg}$ cadmium [16]. Herwijnen et al. [17] reported a high content of cadmium $(128 \mathrm{mg} / \mathrm{kg})$ in soil sample in their study. In our study, the sampling site had been used as an agricultural area for years, but now this site is in a city area. It is believed that, while this site was using for agricultural aim, phosphate fertilizers used for amending the soil and because of this, the Cd content of this soil sample is high.

Table 1

Characterization of soil and compost samples

\begin{tabular}{|l|c|c|}
\hline \multicolumn{1}{|c|}{ Parameter } & Soil & MSW compost \\
\hline $\mathrm{pH}$ & 7.0 & 7.90 \\
\hline$E C, \mu \mathrm{S} / \mathrm{cm}$ & 298.00 & - \\
\hline Moisture, wt. \% & 3.15 & 16.00 \\
\hline $\mathrm{C}, \%$ & 3.42 & 11.32 \\
\hline $\mathrm{N}, \mathrm{wt} \%$ & 0.545 & 1.00 \\
\hline TOC, g/kg & 34.24 & - \\
\hline $\mathrm{H}, \mathrm{wt} . \%$ & 0.95 & 1.82 \\
\hline $\mathrm{Cd}, \mathrm{mg} / \mathrm{kg}$ & 181.64 & 1.00 \\
\hline $\mathrm{Cu}, \mathrm{mg} / \mathrm{kg}$ & 48.89 & 127.00 \\
\hline $\mathrm{Ni}, \mathrm{mg} / \mathrm{kg}$ & 44.64 & 28.00 \\
\hline Available $\mathrm{P}, \mathrm{mg} / \mathrm{kg}$ & 6.50 & $-\mathrm{s}$ \\
\hline
\end{tabular}

$\mathrm{pH}$ of soil should be considered one of the most important factors in the control of the mobility and bioavailability of metals in the soil. If the soil has high $\mathrm{pH}$, a decrease of heavy metal mobility occurs due to the formation of precipitates, by increasing the number of adsorption sites and decreasing the competition of $\mathrm{H}^{+}$for adsorption. In this situation, also the metal stability with humic substances is increased $[18,19]$.

Table 2

$\mathrm{pH}$ in soil-compost mixture in pots at the end of every period

\begin{tabular}{|l|c|c|c|c|}
\hline \multicolumn{1}{|c|}{ Treatment } & 0 days & 30 days & 60 days & 90 days \\
\hline Original soil (OS) & 7.0 & - & - & - \\
\hline Control (C) & 7.0 & 6.8 & 6.6 & 6.4 \\
\hline C0 & 7.0 & 6.8 & 6.7 & 6.5 \\
\hline C1 & 7.1 & 6.8 & 6.7 & 6.6 \\
\hline C3 & 7.2 & 7.0 & 6.9 & 6.8 \\
\hline
\end{tabular}


$\mathrm{pH}$ values of soil and soil-compost mixture in pots (Table 2) were measured at the end of every month. They tended to decrease slightly in time. However, as the amount of compost added to soil increased, this decreasing trend in $\mathrm{pH}$ values decreased and $\mathrm{pH}$ value was observed to remain around 7 . Some authors $[20,21]$ also reported that $\mathrm{pH}$ decreased in time after adding compost to the soil and that this might result from the decomposition and the mineralization of the organic matter, which increased the $\mathrm{CO}_{2}$ levels. However, this was reported to generally occur when $\mathrm{pH}$ of original soil is low and when higher amounts of compost are added [1,22].

Table 3

$\mathrm{C}, \mathrm{H}, \mathrm{Ni}, \mathrm{Cd}$ and $\mathrm{Cu}$ values in soil samples at the end of 90 day period

\begin{tabular}{|c|c|c|c|c|c|}
\hline Sample & $\begin{array}{c}\mathrm{C} \\
\text { [wt. \%] }\end{array}$ & $\begin{array}{c}\mathrm{H} \\
\text { [wt. \%] }\end{array}$ & $\begin{array}{c}\mathrm{Ni} \\
{[\mathrm{mg} / \mathrm{kg}]}\end{array}$ & $\begin{array}{c}\mathrm{Cd} \\
{[\mathrm{mg} / \mathrm{kg}]}\end{array}$ & $\begin{array}{c}\mathrm{Cu} \\
{[\mathrm{mg} / \mathrm{kg}]}\end{array}$ \\
\hline OS & 3.42 & 0.95 & 44.64 & 181.64 & 48.89 \\
\hline $\mathrm{C}$ & 4.67 & 1.26 & 44.64 & 181.64 & 48.89 \\
\hline C0 & 2.90 & 0.98 & 44.64 & 181.64 & 48.89 \\
\hline C1 & 1.82 & 5.18 & 44.71 & 181.65 & 49.22 \\
\hline C3 & 2.65 & 0.96 & 44.86 & 181.65 & 49.87 \\
\hline
\end{tabular}

Herwijen et al. [17] reported that applying composts of various origin in soils contaminated with metals had different effects on different metals. The results of the study of Carbonell et al. [11] showed that MSW compost increased $\mathrm{Cu}, \mathrm{Pb}$ and $\mathrm{Zn}$ contents in soil. In this study, analysis of total metal concentrations revealed that as the amount of compost added to soil samples increased, total metal concentrations for all analyzed metals $(\mathrm{Ni}, \mathrm{Cd}, \mathrm{Cu})$ did not change (Table 3$)$.

Table 4

Concentrations of metals in various fractions of original soil and soil samples at the end of 90 day period (sequential extraction results) $[\mathrm{mg} / \mathrm{kg}]$

\begin{tabular}{|c|c|c|c|c|c|c|c|c|c|c|c|c|}
\hline \multirow{2}{*}{ Sample } & \multicolumn{3}{|c|}{$\begin{array}{c}\text { Soil solution } \\
\text { in exchangeable } \\
\text { forms }\end{array}$} & \multicolumn{3}{|c|}{$\begin{array}{c}\text { Associated } \\
\text { with } \mathrm{OM}\end{array}$} & \multicolumn{3}{c|}{$\begin{array}{c}\text { Extractable } \\
\text { with a strong chelator }\end{array}$} & \multicolumn{4}{c|}{ Residual } \\
& $\mathbf{N i}$ & $\mathrm{Cd}$ & $\mathrm{Cu}$ & $\mathrm{Ni}$ & $\mathrm{Cd}$ & $\mathrm{Cu}$ & $\mathrm{Ni}$ & $\mathrm{Cd}$ & $\mathrm{Cu}$ & $\mathrm{Ni}$ & $\mathrm{Cd}$ & $\mathrm{Cu}$ \\
\hline $\mathrm{OS}$ & 7.81 & $\mathrm{ND}$ & 10.28 & 13.44 & 143.62 & 15.16 & 12.77 & $\mathrm{ND}$ & 1.33 & 10.62 & 38.02 & 22.12 \\
\hline $\mathrm{C}$ & 7.69 & $\mathrm{ND}$ & 11.17 & 14.85 & 147.79 & 10.49 & 13.87 & $\mathrm{ND}$ & 1.65 & 8.23 & 33.86 & 25.58 \\
\hline $\mathrm{C} 0$ & 7.84 & $\mathrm{ND}$ & 10.99 & 26.32 & 149.17 & 33.90 & 8.65 & $\mathrm{ND}$ & 0.70 & 1.83 & 32.48 & 3.30 \\
\hline $\mathrm{C} 1$ & 7.80 & $\mathrm{ND}$ & 10.38 & 21.51 & 159.57 & 4.49 & 12.77 & $\mathrm{ND}$ & 1.10 & 2.62 & 22.07 & 33.25 \\
\hline $\mathrm{C} 3$ & 7.73 & $\mathrm{ND}$ & 11.12 & 24.46 & 145.25 & 7.58 & 10.42 & $\mathrm{ND}$ & 1.01 & 2.24 & 36.40 & 30.16 \\
\hline
\end{tabular}

$\mathrm{ND}$ - not detected. 
Analysis of various forms of nickel in soil revealed that Ni was associated with organic matter and that it can be extracted by a strong chelator (Table 4). It was found that he concentrations of $\mathrm{Ni}$, which was initially $7.81 \mathrm{mg} / \mathrm{kg}$ in original soil, in soil solution and in exchangeable form remained almost at the same level at the end of 90 day period in control soils in which no plants were grown and in soils in which compost was added and plants were grown. The concentration of $\mathrm{Ni}$ in associated with $\mathrm{OM}$ form was $13.44 \mathrm{mg} / \mathrm{kg}$ in original soil, while this form of $\mathrm{Ni}$ approximately doubled in soils in which plants were grown $(21.51-26.32 \mathrm{mg} / \mathrm{kg})$. The concentration of the form of $\mathrm{Ni}$ that can be extracted by a strong chelator significantly decreased in soil without compost (C0) in which plants were grown (from $12.77 \mathrm{mg} / \mathrm{kg}$ to $8.65 \mathrm{mg} / \mathrm{kg}$ ) while no significant variation was observed in other samples. The concentration of $\mathrm{Ni}$ in residual form significantly decreased in samples in which plants were grown (from $10.62 \mathrm{mg} / \mathrm{kg}$ to $1.83-2.62 \mathrm{mg} / \mathrm{kg}$ ), however it almost remained unchanged in control sample (Table 5). Similarly, in studies carried out by Achiba et al. [18], it was reported that the concentration of $\mathrm{Ni}$ in associated with $\mathrm{OM}$ form increased in soil that was treated with compost. This could be referred to the fact that $\mathrm{Ni}$ was present at much higher watersoluble levels in municipal solid waste compost [18, 23, 24].

Table 5

Heavy metal amounts in plant samples measured at the end of each period $[\mathrm{mg} / \mathrm{kg}]$

\begin{tabular}{|c|c|c|c|c|c|c|c|c|c|}
\hline \multirow{2}{*}{ Sample } & \multicolumn{3}{|c|}{30 days } & \multicolumn{3}{c|}{60 days } & \multicolumn{3}{c|}{90 days } \\
\cline { 2 - 11 } & $\mathrm{Ni}$ & $\mathrm{Cd}$ & $\mathrm{Cu}$ & $\mathrm{Ni}$ & $\mathrm{Cd}$ & $\mathrm{Cu}$ & $\mathrm{Ni}$ & $\mathrm{Cd}$ & $\mathrm{Cu}$ \\
\hline $\mathrm{C} 0$ & 8.68 & 0.12 & 39.98 & 5.01 & 0.12 & 29.25 & & & \\
\hline $\mathrm{C} 1$ & 11.85 & 0.17 & 49.22 & 20.23 & 0.30 & 94.96 & 8.46 & 0.19 & 23.38 \\
\hline $\mathrm{C} 3$ & 12.18 & 0.16 & 79.14 & 14.15 & 0.24 & 40.98 & 35.03 & 0.34 & 136.4 \\
\hline
\end{tabular}

Liu et al. [25] reported that adding compost into contaminated soil reduced the mobility of $\mathrm{Cd}$ and that compost can be used for remediation purposes. Carbonell et al. [11] showed that bioavailability of metals (for $\mathrm{Cu}, \mathrm{Pb}$ and $\mathrm{Zn}$ ) increased in soils that were amended with MSW compost. In this study, analysis of the concentrations of Cd revealed that $\mathrm{Cd}$ was only found in associated with $\mathrm{OM}$ and residual form (Table 4). Cd contents in associated with OM form increased approximately by $12 \mathrm{mg} / \mathrm{kg}$ in C1. Furthermore, $\mathrm{Cd}$ concentration in residual form in this soil sample decreased by approximately $12 \mathrm{mg} / \mathrm{kg}$; in other words, Cd changed its occurrence from residual form to $\mathrm{OM}$ form (Table 4). Similarly, it was found in previous studies that the amount of Cd associated with OM increased when compost was added to soil samples mainly in residual form in control samples [11, 18]. Bolan et al. [2] reported that if the $\mathrm{pH}$ value of soil is greater than 6 , the activity of metal ions decreases and this has been referred to the increase in $\mathrm{pH}$ dependent surface charge on oxides of $\mathrm{Fe}, \mathrm{Al}$, and $\mathrm{Mn}$, chelation by organic matter, or precipitation of metal hydroxides. In acidic soils, metal activity (for 
$\mathrm{Cd}$ and $\mathrm{Pb}$ ) was reported to decrease with the increase of $\mathrm{pH}$ [2]. Wu et al. [8] reported that $\mathrm{Cd}$ mobility decreased in soils that were amended with compost.

Analysis of $\mathrm{Cu}$ concentrations showed that $\mathrm{Cu}$ changed from residual form to $\mathrm{OM}$ form in $\mathrm{C} 0$ soil samples. On the other hand, $\mathrm{Cu}$ changed from associated $\mathrm{OM}$ form to residual form in $1 \%$ of compost soil samples $(\mathrm{C} 1)$ in which plants were grown. In soil samples with $3 \%$ of compost (C3), it was observed that the concentration of $\mathrm{Cu}$ in the form of associated OM was lower than the control sample (approximately $3 \mathrm{mg} / \mathrm{kg}$ ), while the concentration in residual form increased approximately at the same level. Considering all soil samples, it was observed that $\mathrm{Cu}$ concentrations at exchangeable form did not show a significant variation (Table 4). On the contrary, in a study carried out by Achiba et al. [18], it was reported that adding compost into soil sample increased the concentration of $\mathrm{Cu}$ in $\mathrm{OM}$ form. Achiba et al. [18] also reported that amendment of contaminated soil with compost can increase metal mobility and leaching. Liu et al. [25] reported that adding compost into contaminated soil reduced metal mobility. The results of this study showed that OM associated forms of nickel and cadmium increased, however $\mathrm{Cu}$ changed into residual form after compost addition (Table 4). This can be attributed to the fact that $\mathrm{Cu}$ amount in compost $(127.00 \mathrm{mg} / \mathrm{kg})$ was significantly higher than the amount in soil $(45.00 \mathrm{mg} / \mathrm{kg})$.

Achiba et al. [18] and Pardo et al. [26] reported that increase of organic matter content in soil led to formation of insoluble organometallic complexes by the metals in the soil and reduced the mobility of these metals. In the same study, the authors reported formation of soluble metal complexes with soluble organic ligands (for example fulvic acids, amino acids) contained in soil. Pardo et al. [26] reported that organic amendment of soil did not cause a significant changes in the available fractions of metals. Our results showed that the amount of $\mathrm{Cd}$ and their $\mathrm{OM}$ associated concentrations were higher than those of $\mathrm{Ni}$ and $\mathrm{Cu}$ and that this can be attributed to the fact that $\mathrm{Cd}$ formed soluble metal complexes with dissolved organic ligands.

\subsection{PLANTS}

The tendency of uptake of metals such as lead, cadmium and zinc by plants increase by the increased concentrations of these metals in soil [27]. Shao-qi et al. [28], Karami et al. [7] and $\mathrm{Wu}$ et al. [8] found that transfer of metals from the soil that is amended with compost to the plants decreased. On the contrary, Carbonell et al. [11] reported that the contents of metals in soils and the amount that the plants can uptake increased after adding compost into the soil.

All the plants in pots without compost died at the end of the 90 day period. An analysis of metal concentrations on plant samples showed that although Cd concentration in soil was significantly higher than other metals, the transfer of $\mathrm{Cd}$ to the plant was much lower when compared to other metals (maximum $0.34 \mathrm{mg} / \mathrm{kg}$ at the end of 90 day period) (Table 5). Chelating agents, such as ethylene-diamine tetraacetic acid (0.05 M 
EDTA), have often been found to be more dependable in estimating the plant availability of metals, because the chelating agents are more effective in removing soluble metal-organic complexes that are potentially bioavailable [2]. The results of sequential extraction revealed that $\mathrm{Cd}$ is found in soil in $\mathrm{OM}$ associated and residual forms (Table 4). Therefore, lower amounts of $\mathrm{Cd}$ are believed to be transferred to plant when compared to other metals ( $\mathrm{Ni}$ and $\mathrm{Cu}$ ).

As the compost amount increased in plants that grew in pots with compost added soil samples, the amount of metals in plants $(\mathrm{Ni}, \mathrm{Cd}, \mathrm{Cu})$ increased at the end of 90 day period (Table 5). Herwijen et al. [17] reported that immobilization and leaching of metals depend on the structure of metalorganic complexes. In another study, it was reported that adding compost into the soil can increase the mobility of some elements (As and $\mathrm{Sb})$ or can reduce the mobility and uptake of some elements $(\mathrm{Zn}, \mathrm{Cu}$ and $\mathrm{Pb}$ ) [12]. The amounts of $\mathrm{Ni}$ and $\mathrm{Cu}$ that are transferred to the plant were higher than the amounts of $\mathrm{Cd}$. It is believed that presence of $\mathrm{Cd}$ in soil in associated with $\mathrm{OM}$ form prevents transfer of $\mathrm{Cd}$ to the plant.

\section{CONCLUSIONS}

It was observed in this study that as the amount of compost added to the soil increased, total $\mathrm{Ni}, \mathrm{Cd}$ and $\mathrm{Cu}$ concentrations increased as well. Results of sequential extraction showed that concentrations of Ni which is initially associated with $\mathrm{OM}$ and can be extracted by a strong chelator form in the soil, in OM form in compost added soils increased, while the concentrations in residual form decreased at the end of 90 day period. In other words, $\mathrm{Ni}$ became more mobile. The same condition is valid for $\mathrm{Cd}$. As for $\mathrm{Cu}$, it was observed that associated with $\mathrm{OM}$ form concentrations decreased, while the concentrations in residual form increased at the end of 90 day period.

$\mathrm{Cd}$, which was found in significantly high amounts in soil $(181.64 \mathrm{mg} / \mathrm{kg})$, was transferred to the plant at very low amounts. However, $\mathrm{Cu}$ amount identified in plants was observed to increase as the amount of compost added to the soil increased and that it accumulated in the plant in higher amounts than $\mathrm{Ni}$ and $\mathrm{Cd}$.

In conclusion, it was observed that MSW compost can be beneficial to prevent the transfer of Cd from the soil to the plant. However, since the used MSW compost contained higher amounts of $\mathrm{Cu}(127.00 \mathrm{mg} / \mathrm{kg})$ than the soil, it did not show the same effect on $\mathrm{Cu}$. The transfer of $\mathrm{Ni}$ to the plant was higher when compared to $\mathrm{Cd}$. This study indicates that amendment the soils that are contaminated with heavy metals using composts might not always produce positive results. Therefore, it can be recommended to use another soil amender (for example biochar) in combination with the compost. 


\section{ACKNOWLEDGEMENTS}

This work was supported by Scientific Research Projects Coordination Unit of Istanbul University. Project No. 30740.

\section{REFERENCES}

[1] DișLi E., Batch and column experiments to support heavy metals ( $\mathrm{Cu}, \mathrm{Zn}$ and $\mathrm{Mn})$ transport modeling in alluvial sediments, between the Mogan Lake and the Eymir Lake, Gölbaşl, Ankara, Groundwater Monitor. Remed., 2010, 30 (3), 125.

[2] Bolan N., Kunhikrishnan A., Thangarajan R., Kumpiene J., Park J., Makino T., Kirkham M.B., SCHECKEL K., Remediation of heavy metal(loid)s contaminated soils - to mobilize or to immobilize?, J. Hazard. Mater., 2014, 266, 141.

[3] Beesley L., Inneh O.S., Norton G.J., Moreno-Jimenez E., Pardo T., Clemente R., Dawson J.J.C., Assessing the influence of compost and biochar amendments on the mobility and toxicity of metals and arsenic in a naturally contaminated mine soil, Environ. Pollut., 2014, 186, 195.

[4] Zhang H., Schuchardt F., Li G., YANG J., YANG Q., Emission of volatile sulfur compounds during composting of municipal solid waste (MSW), Waste. Manage., 2013, 33, 957.

[5] BALDwin K.R., SHELton J.E., Availability of heavy metals in compost-amended soil, Biores. Tech., 1999, 69 (1), 1.

[6] Sмiтн S.R., A critical review of the bioavailability and impacts of heavy metals in municipal solid waste composts compared to sewage sludge, Environ. Inter., 2009, 35 (1), 142.

[7] Karami N., Clemente R., Moreno-Jiménez E., LePP N.W., BEeSley L., Efficiency of green waste compost and biochar soil amendments for reducing lead and copper mobility and uptake to ryegrass, J. Hazard. Mater., 2011, 191 (1-3), 41.

[8] Wu F.L., Lin D.Y., Su D.C., The effect of planting oilseed rape and compost application on heavy metal forms in soil and Cd and Pb uptake in rice, Agric. Sci. China., 2011, 10 (2), 267.

[9] Shulan Zhao S., Lian F., Duo L., EDTA-assisted phytoextraction of heavy metals by turfgrass from municipal solid waste compost using permeable barriers and associated potential leaching risk, Biores. Tech., 2011, 102 (2), 621.

[10] Zorpas A.A., Constantinides T., Vlyssides A.G., Haralambous I., Loizidou M., Heavy metal uptake by natural zeolite and metals partitioning in sewage sludge compost, Biores. Tech., 2000, 72 (2), 113.

[11] Carbonell G., Miralles De Imperial R., Torrijos M., Delgado M., Rodriguez J.A., Effects of municipal solid waste compost and mineral fertilizer amendments on soil properties and heavy metals distribution in maize plants (Zea mays L.), Chemosphere, 2011, 85 (10), 1614.

[12] Clemente R., Hartley W., Riby P., Dickinson N.M., LePP N.W., Trace element mobility in a contaminated soil two years after field-amendment with a greenwaste compost mulch, Environ. Pollut., 2010, 158, 1644.

[13] WatANABE F.S., OLSEN S.R., Test of an ascorbic acid method for determining phosphorus in water and $\mathrm{NaHCO}_{3}$ extracts from soil, Soil. Sci. Soc. Am. Proc., 1965, 29, 677.

[14] Pardo T., Clemente R., Bernal M.P., Effects of compost, pig slurry and lime on trace element solubility and toxicity in two soils differently affected by mining activities, Chemosphere, 2011, 84 (5), 642.

[15] Clemente R., Bernal M.P., Fractionation of heavy metals and distribution of organic carbon in two contaminated soils amended with humic acids, Chemosphere, 2006, 64, 1264.

[16] Coок M.E., Morrow H., Anthropogenic Sources of Cadmium in Canada, National Workshop on Cadmium Transport Into Plants, Canadian Network of Toxicology Centres, Ottawa, Ontario, Canada, June 20-21 1995. 
[17] Herwijnen R.V., Hutchings T.R., Altabbaa A., Moffat A.J., Johns M.L., Ouki S.K., Remediation of metal contaminated soil with mineral-amneded composts, Environ. Pollut., 2007, 150, 347.

[18] Achiba W.B., Gabteni N., Lakhdar A., Laing G.D., Verloo M., Jedidi N., Gallali T., Effects of 5-year application of municipal solid waste compost on the distribution and mobility of heavy metals in a Tunisian calcareous soil, Agricul. Ecosys. Environ., 2009, 130, 156.

[19] Pigozzo A.T.G., Lenzi E., Junior J.L., SCAPIN C., Da Costa A.C.S., Transition metal rates in latosol twice treated with sewage sludge, Brazil. Arch. Biol. Technol., 2006, 49 (3), 515.

[20] Mohammad M.J., Athamnen B.M., Changes in soil fertility and plant uptake of nutrients and heavy metals in response to sewage sludge application to calcareous soils, J. Agron., 2004, 3 (3), 229.

[21] ZinATI G.M., Li Y.C., BRYAN H.H., Utilization of compost increases organic carbon and its humin, humic and fulvic acid fractions in calcareous soil, Compost. Sci. Util., 2001, 9 (2), 156.

[22] Mendoza J., Garrido T., CAStillo G., Martin N.S., Metal availability and uptake by sorghum plants grown in soils amended with sewage from different treatments, Chemosphere, 2006, 60, 1033.

[23] He X.T., Traina S.J., Logan T.J., Chemical properties of municipal solid waste composts, J. Environ. Qual., 1992, 21, 318.

[24] Tidsell S.E., BresLin V.T., Characterization and leaching of elements from municipal solid waste compost, J. Environ. Qual., 1995, 24, 827.

[25] Liu L., Chen H., CAi P., LiAng W., HuANG Q., Immobilization and phytotoxicity of Cd in contaminated soil amended with chicken manure compost, J. Hazard. Mater., 2009, 163, 563.

[26] Pardo T., Martínez-Fernández D., Clemente R., Walker D.J., Bernal M.P., The use of olive-mill waste compost to promote the plant vegetation cover in a trace-element-contaminated soil, Environ. Sci. Pollut. Res., 2014, 21 (2), 1029.

[27] Martin T.A., Ruby M.V., Review of in situ remediation technologies for lead, zinc, and cadmium in soil, Remediation, 2004, 14, 35.

[28]Zноu S.-Q., LU W.-D., ZHOU X., Effects of heavy metals on planting watercress in kailyard soil amended by adding compost of sewage sludge, Process. Safety Environ. Protect., 2010, 88, 263. 